\title{
Pathological and immunological responses associated with differential survival of Chinook salmon following Renibacterium salmoninarum challenge
}

\author{
David C. Metzger ${ }^{1,2}$, Diane G. Elliott ${ }^{1}$, Andrew Wargo ${ }^{3}$, Linda K. Park ${ }^{2}$, \\ Maureen K. Purcell ${ }^{1, *}$ \\ ${ }^{1}$ Western Fisheries Research Center, US Geological Survey, 6505 NE 65th Street, Seattle, Washington 98115, USA \\ ${ }^{2}$ Northwest Fisheries Science Center, National Marine Fisheries Service, 2725 Montlake Boulevard East, Seattle, \\ Washington 98112, USA \\ ${ }^{3}$ Department of Biology, University of Washington, Box 351800, Seattle, Washington 98195, USA
}

\begin{abstract}
Chinook salmon Oncorhynchus tshawytscha are highly susceptible to Renibacterium salmoninarum, the causative agent of bacterial kidney disease (BKD). Previously we demonstrated that introduced Chinook salmon from Lake Michigan, Wisconsin (WI), USA, have higher survival following $R$. salmoninarum challenge relative to the progenitor stock from Green River, Washington, USA. In the present study, we investigated the pathological and immunological responses that are associated with differential survival in the 2 Chinook salmon stocks following intra-peritoneal $R$. salmoninarum challenge of 2 different cohort years (2003 and 2005). Histological evaluation revealed delayed appearance of severe granulomatous lesions in the kidney and lower overall prevalence of membranous glomerulopathy in the higher surviving WI stock. The higher survival WI stock had a lower bacterial load at $28 \mathrm{~d}$ post-infection, as measured by reverse-transcriptase quantitative polymerase chain reaction (RT-qPCR). However, at all other time points, bacterial load levels were similar despite higher mortality in the more susceptible Green River stock, suggesting the possibility that the stocks may differ in their tolerance to infection by the bacterium. Interferon- $\gamma$, inducible nitric oxide synthase (iNOS), Mx-1, and transferrin gene expression were up-regulated in both stocks following challenge. A trend of higher iNOS gene expression at later time points ( $\geq 28 \mathrm{~d}$ post-infection) was observed in the lower surviving Green River stock, suggesting the possibility that higher iNOS expression may contribute to greater pathology in that stock.
\end{abstract}

KEY WORDS: Bacterial kidney disease $\cdot$ BKD $\cdot$ Histopathology $\cdot$ Reverse-transcriptase quantitative $\mathrm{PCR} \cdot$ Interferon $\cdot$ Immune-mediated pathology $\cdot$ Resistance $\cdot$ Tolerance

Resale or republication not permitted without written consent of the publisher

\section{INTRODUCTION}

Renibacterium salmoninarum is a Gram-positive intracellular bacterium and the causative agent of bacterial kidney disease (BKD), a significant disease of salmonid populations worldwide (Wiens \& Kaattari 1999). R. salmoninarum is widespread in natural and captive populations of Chinook salmon Oncorhynchus tshawytscha in the Pacific Northwest region of North America (Elliott et al. 1997, Rhodes et al. 2006). Chinook salmon have been shown to be particularly sus- ceptible to BKD relative to other salmonid species (Fryer \& Lannan 1993), and there is limited understanding of what constitutes a protective immune response to $R$. salmoninarum in Chinook salmon. Salmon infected with $R$. salmoninarum produce an antibody response, but this response is not necessarily correlated with protection (Bartholomew et al. 1991, Jansson \& Ljungberg 1998). Several studies have examined immune gene expression changes early after $R$. salmoninarum infection and demonstrated differential regulation of key immune genes (e.g. interferon pathway genes, in- 
terleukins and lymphocyte-associated gene markers), as compared with controls (Campos-Perez et al. 2000, Grayson et al. 2002, Rhodes et al. 2009).

Chinook salmon were introduced into Lake Michigan in the 1960s, using eggs derived from the Green River Chinook salmon stock from Washington State (WA), and there has been minimal genotypic divergence between these 2 stocks since introduction (Weeder et al. 2005). Recently, we reported that a Lake Michigan stock of Chinook salmon from Wisconsin (WI) has higher survival following Renibacterium salmoninarum challenge relative to the progenitor Green River stock (Purcell et al. 2008). It is not known which factors contributed to the phenotypic divergence in $R$. salmoninarum survival between the 2 populations. However, the Lake Michigan population of Chinook salmon experienced large mortality events associated with $R$. salmoninarum in the late 1980s (Holey et al. 1998), suggesting a possible role for pathogen-driven selection (Purcell et al. 2008).

Intracellular bacterial pathogens have a number of hallmarks, including pathology associated with granulomatous lesions, low direct toxicity to host tissues with pathology more typically resulting from host immune responses, long incubation times developing into a chronic disease state with the initial infection often disassociated from the onset of disease, and protective immunity that is cell-mediated rather than antibodybased (Kaufman 1999). Renibacterium salmoninarum can survive intracellularly within macrophages (Gutenberger et al. 1997) and causes a chronic disease typified by granulomatous lesions in internal organs such as the kidney (Bruno 1986). The goal of the present study was to investigate the histopathological changes and immune responses associated with differential survival in the WI and Green River stocks. In this study, we assessed disease progression by histopathology in the 2 stocks following $R$. salmoninarum infection using the 2003 cohort year. Next, we examined differences in bacterial load and immune responses following challenge using the 2005 cohort year. These results were used to address if higher survival in the WI stock was associated with (1) reduced immune-mediated pathology, (2) overall enhanced or dampened immune responses, or (3) enhanced resistance or tolerance of the bacterium by the host.

\section{MATERIALS AND METHODS}

\section{Obtaining specific pathogen-free Chinook salmon.} Brood stock screening of spawning adults is effective in minimizing the vertical transmission of Renibacterium salmoninarum to progeny but cannot guarantee that all fish are completely specific pathogen free (SPF)
(Pascho et al. 1991). Adult Chinook salmon returning in the fall of 2003 and 2005 were used in this study to create SPF fish. The Green River spawning adults were obtained from the Soos Creek Hatchery, Rainier Complex (WA Department of Fish and Wildlife). The WI spawning adults were taken from the Strawberry Creek weir (Wisconsin Department of Natural Resources). Gametes were tested for the presence of $R$. salmoninarum antigens as previously described (Purcell et al. 2008). Briefly, kidney tissue from both males and females and female ovarian fluids were tested by double-polyclonal antibody ELISA (ELISA II) (Pascho et al. 1991). Only individuals with negative or low ELISA values were used to create progeny; ELISA categories were defined previously (Purcell et al. 2008).

Renibacterium salmoninarum injection challenge. The R. salmoninarum isolate ATCC 33209 (type strain isolated from Chinook salmon, Mackenzie River, OR) was used in this study. Bacterial cells in KDM2 broth medium (Evelyn 1977, Evelyn et al. 1990) were cultivated as previously described (Purcell et al. 2008). Centrifugation was used to pellet the bacterial culture, and the pellet was suspended in sterile $1 \times$ phosphatebuffered saline-peptone $(0.1 \% \mathrm{w} / \mathrm{v})$ (PBS-peptone). The concentration of bacterial cells in this suspension was enumerated by membrane-filtration fluorescent antibody test (MF-FAT) (Elliott \& Barila 1987) prior to challenge. Serial dilutions of bacterial cultures were plated onto KDM2 agar medium, and final challenge doses were reported as colony forming units (CFU) determined by plate counts.

Renibacterium salmoninarum challenges of the 2003 and 2005 WI and Green River Chinook salmon at $12{ }^{\circ} \mathrm{C}$ have been described elsewhere (Purcell et al. 2008). Briefly, $10 \mathrm{~g}$ fish from each stock were given an intraperitoneal (IP) injection of $100 \mu \mathrm{l}$ of PBS-peptone containing $R$. salmoninarum (2003 cohort year, $1.0 \times$ $10^{6} \mathrm{CFU} \mathrm{fish}^{-1}$; 2005 cohort year; $9.5 \times 10^{5} \mathrm{CFU} \mathrm{fish}^{-1}$ ); mock controls received only PBS-peptone. In 2003, a total of 100 fish from the WI and Green River stocks were injected and held separately in 2761 tanks. Five fish from each group were sampled at Days 0, 14, 28, $42,56,70$, and 84 for histopathology. In 2005, fish were separated into 3 replicate 2761 tanks and challenged with $R$. salmoninarum (125 fish per replicate tank per stock; total of 375 Green River and 375 WI fish). Mock control groups consisted of 100 fish from each stock that were IP injected with $100 \mu \mathrm{l}$ of PBS-peptone and held in separate 2761 tanks. Eight fish per replicate tank (8 fish total for the mock group and 24 fish total for the $R$. salmoninarum groups) were sampled at 7,14 , 28, 44, and $71 \mathrm{~d}$ post-infection (dpi). For the 2005 fish, whole kidneys were removed from sampled fish, homogenized, flash frozen in liquid nitrogen, and stored at $-80^{\circ} \mathrm{C}$ until use. 
Histopathology. Whole fish representing the 2003 cohort year were opened along the abdominal wall and fixed at a ratio of 1 part body weight: 10 parts $10 \%$ neutral buffered formalin. Anterior kidney, posterior kidney, heart, spleen, pancreatic tissue, and liver were sampled and subjected to routine processing and paraffin embedding for histological examination as previously described (Kurath et al. 2006). The histological samples were stained with hematoxylin and eosin (H\&E) and examined for presence or absence of pathology. Evaluations included size (scale 0 to 3) and distribution (scale 0 to 3 ) of granulomatous lesions and severity of inflammation (scale 0 to 3 ) and necrosis (scale 0 to 3). Scores were added together to obtain an overall severity measure for each tissue type. Thickening of the capillary basement membranes of kidney glomeruli was also examined and scored for overall severity, on a scale that included scores for distribution ( 0 to 3 ) and severity (0 to 3 ) of glomerular basement membrane thickness.

RNA extraction and cDNA synthesis. RNA was extracted from whole kidney tissue, sampled from the 2005 cohort year, as previously described (Purcell et al. 2004) using the RNeasy Mini Kit with in-column DNAse I (Qiagen) treatment. Synthesis of cDNA using random hexamer and oligo-dT priming was conducted as previously described (Purcell et al. 2004). Controls containing all reagents and template RNA but lacking reverse transcriptase enzyme were included to detect genomic DNA contamination.

Bacterial load. Expression of the Renibacterium salmoninarum major soluble antigen (msa) (Chien et al. 1992, Chase et al. 2006) or abc transporter permease (Rhodes et al. 2006) genes was measured by reverse-transcriptase quantitative PCR (RT-qPCR) as a proxy of bacterial load. Since these assays measure RNA rather than DNA, RT-qPCR may be better able to discriminate live from dead bacteria. One caveat is that differential regulation of $R$. salmoninarum genes may occur during the infection cycle; however, a previous study in coho salmon (Oncorhynchus kisutch) found good correlation between msa mRNA and genomic DNA copy number in infected samples (Suzuki \& Sakai 2007). Our RT-qPCR methodology has been previously described in detail (Purcell et al. 2004). The msa RTqPCR was performed as previously described (Chase et al. 2006) with the following modifications: (1) the probe was labeled with a 5' 6-carboxyfluorescein (FAM) and 3' non-fluorescent quencher (NFQ) and a minor grove binding (MGB) linker (probe purchased from Applied Biosystems) and (2) the target template was cDNA rather than genomic DNA. The $a b c$ assay was performed as described (Rhodes et al. 2006) but again targeted cDNA rather than genomic DNA. Bacterial load was assayed in the same experimental
cDNA samples as the host immune genes described below. $R$. salmoninarum DNA extracted from culture enumerated by MF-FAT (Elliott \& Barila 1987) was used to create an absolute standard curve and estimate bacteria per reaction well. Bacterial load data were $\log _{10}$ transformed prior to analyses.

Sequencing and expression of Chinook salmon immune genes. Small regions of key Chinook salmon immune genes were sequenced to develop gene expression assays. The forward and reverse primers for the RT-qPCR assays (based on rainbow trout sequences; trout GenBank numbers listed in Table 1) were used to PCR amplify the interferon gamma (IFN- $\gamma$ ), iNOS, and Mx-1 genes from Chinook salmon. However, the T-cell receptor beta chain (TCR- $\beta$ ) and secreted form of immunoglobulin- $\mu$ (IgM-sec) genes were amplified and sequenced using a different set of primers (not the RT-qPCR primers listed in Table 1). TCR- $\beta$ was amplified using the forward primer 5 '-gag atc tcc aag gtc aaa gtg gg-3' and reverse primer $5^{\prime}$-ctt gat cac atg gaa gaa tca aca c-3'. IgM-sec was amplified using the forward primer $5^{\prime}$-gag caa tgg gac agt att cta ctg c-3' and the reverse primer 5'-acc ggc tca tcg tca aca a-3'. The transferrin gene has been previously reported in Chinook salmon (Ford 2001). PCR amplification, cloning, and sequencing were conducted using standard methods previously described (Purcell et al. 2004). Chinook salmon partial cDNA sequences were submitted to GenBank (Table 1).

Primer and probe sequences used for the Chinook salmon RT-qPCR assays are provided in Table 1. To assess PCR efficiency, we used serial dilutions of a standard cDNA preparation. All specific gene data were normalized against expression of a housekeeping gene (acidic ribosomal phosphoprotein P0; ARP) (Pierce et al. 2004, Purcell et al. 2004). Fold changes in gene expression of the Renibacterium salmoninarum challenge groups were calculated relative to the mock control groups for specific host genes (IFN- $\gamma$, iNOS, Mx-1, transferrin, TCR- $\beta$ and IgM-sec). Fold increase was calculated as (Rs/Rn)/(Ms/Mn) where Rs equals the $R$. salmoninarum challenged group assayed for a specific host gene and Rn represents the $R$. salmoninarum challenged group assayed for the normalizing gene (ARP) and Ms and Mn equal the mock controls assayed for the specific host gene or normalizing gene, respectively.

Statistical analyses. Variation in immune gene expression was analyzed using general linear models (GLM) with normalized gene expression level as the dependent variable and explanatory factors: time (dpi), treatment (mock or Renibacterium salmoninarum challenged) and stock (WI or Green River). Since many samples were not positive for bacterial load using either the msa or abc assays, a separate analysis was conducted to examine the relationship between bacte- 
Table 1. Primer and probe sets for reverse-transcriptase quantitative PCR (RT-qPCR) of Chinook salmon immune genes. Chinook salmon sequences were obtained by designing primers to existing rainbow trout sequences in GenBank. Transferrin has been previously sequenced in Chinook salmon. All other Chinook salmon sequences were generated as part of this study and submitted to GenBank. Forward primer (F); reverse primer (R); dual-labelled Taqman probe (T) labelled with a 3' FAM and 5' Tamra. NA: not applicable (sequence not used in study)

\begin{tabular}{|c|c|c|c|}
\hline \multirow[t]{2}{*}{ Gene } & \multirow{2}{*}{ RT-qPCR primer and probes } & \multicolumn{2}{|c|}{ GenBank no. } \\
\hline & & Rainbow trout & Chinook salmon \\
\hline Interferon gamma & $\begin{array}{l}\text { F: ttgagctttgagggatcttcagtg } \\
\text { R: gtgaactgagcagcattactccatc } \\
\text { T: atccagcccatcaagcagaaacacatcaca }\end{array}$ & AJ616215 & GT897806 \\
\hline Inducible nitric oxide synthase & $\begin{array}{l}\text { F: cctgaagagtgttaccaacgcata } \\
\text { R: cacaccccacacacatagaagt } \\
\text { T: caggtctcccaaaggtctatgtccaggatgtc }\end{array}$ & NM_001124359 & GT897809 \\
\hline Mx-1 & $\begin{array}{l}\text { F: ggttgtgccatgcaacgtt } \\
\text { R: ggcttggtcaggatgcctaat } \\
\text { T: aagatggcacaagaggtggaccctgaag }\end{array}$ & U30253 & GT897808 \\
\hline $\begin{array}{l}\text { Immunuglobulin- } \mu \\
\text { (IgM) secreted }\end{array}$ & $\begin{array}{l}\text { F: ttggtaaagaaagcctacaagaggga } \\
\text { R: gtagaagtcttgacgtagcaagtcagg } \\
\text { T: accggaggagttccacagcgtccat }\end{array}$ & X65261 & GT897807 \\
\hline T-cell receptor-beta chain & $\begin{array}{l}\text { F: agcacccagactgccaagct } \\
\text { R: gaggagccctggaacttcca } \\
\text { T: tcttcatcgctaagagtaccttctatggcctggt }\end{array}$ & AF329700 & GT897810 \\
\hline Transferrin & $\begin{array}{l}\text { F: tggtccctgtcatggtggag } \\
\text { R: tgcagggtttccaggtcaa } \\
\text { T: cctggtgaggcgtcatcctactttgcg }\end{array}$ & NA & AH009645 \\
\hline
\end{tabular}

rial load and gene expression level using only fish with quantifiable msa levels. Once again a GLM analysis was employed with dependent variable normalized gene expression level, covariate normalized msa level (as a proxy for bacterial load), and explanatory factors time, replicate tank $(1,2,3)$, and stock (mock fish had no bacteria so treatment was not relevant). A third analysis was done to examine differences in bacterial load irrespective of immune gene expression level. For this analysis a GLM was implemented with dependent variable normalized msa or $a b c$ level and explanatory factors time, replicate tank, and stock. All analyses were conducted in R (V.2.8.0; www.r-project.org/; accessed December 15, 2009) and normalized gene expression level, normalized msa level, and normalized $a b c$ level were log-transformed to meet test assumptions. For all analyses, maximum models were first tested and non-significant terms were sequentially dropped, starting with higher order interactions, until the minimal significant model was reached. Replicate tank was never significant.

\section{RESULTS}

\section{Survival}

The Renibacterium salmoninarum IP injection challenge of the 2003 cohort year was terminated at $84 \mathrm{dpi}$. The onset of mortality occurred in the WI stock at $41 \mathrm{dpi}$, and mean day to death (MDD) was at 63 dpi. In the Green River stock, the onset of mortality was at $15 \mathrm{dpi}$, and the MDD was $47 \mathrm{dpi}$. The WI and Green River stocks had a total of 30 and 52 mortalities, respectively (100 fish stock ${ }^{-1}$ were initially injected). A simultaneous survival challenge was also conducted (with no fish

Table 2. Summary of the Renibacterium salmoninarum challenges using the 2003 and 2005 cohort years. Year 2003 and 2005 challenges were terminated at 84 and $100 \mathrm{~d}$ post-infection, respectively. Survival estimates are from simultaneous challenges that did not have sampling; the results of the simultaneous challenges are reported by Purcell et al. (2008)

\begin{tabular}{|llcccccc|}
\hline Cohort & Stock & $\begin{array}{c}\text { Total } \\
\text { number } \\
\text { challenged }\end{array}$ & $\begin{array}{c}\text { No. of } \\
\text { mortalities } \\
\text { observed }\end{array}$ & $\begin{array}{c}\text { No. of } \\
\text { fish } \\
\text { sampled }\end{array}$ & $\begin{array}{c}\text { Onset of } \\
\text { mortality } \\
\text { (d) }\end{array}$ & $\begin{array}{c}\text { Mean } \\
\text { day to } \\
\text { death }\end{array}$ & $\begin{array}{c}\text { Survival in } \\
\text { non-sampled } \\
\text { challenge (\%) }\end{array}$ \\
\hline 2003 & Lake Michigan, WI & 100 & 30 & 30 & 41 & 63 & 80 \\
& Green River, WA & 100 & 52 & 30 & 15 & 47 & 30 \\
& Lake Michigan,WI & 375 & 176 & 120 & 39 & 62 & 41 \\
\hline
\end{tabular}


sampling), and these results have been reported elsewhere (Purcell et al. 2008). Briefly, survival was $80 \%$ in the WI stock and $30 \%$ in the Green River stock (Table 2).

In the 2005 injection challenge, the onset of mortality in the WI stock occurred at $39 \mathrm{dpi}$, and the MDD was 68 dpi. Onset of mortality in the Green River stock occurred on Day 30, and MDD was 62 dpi. At 100 dpi, a total of 176 mortalities were recorded in the WI stock and 218 mortalities in the Green River stock (of 375 fish initially injected stock ${ }^{-1}$ ). A simultaneous survival challenge with no fish sampling was also conducted in 2005 (Purcell et al. 2008), and survival was $41 \%$ in the WI stock and $21 \%$ in the Green River stock (Table 2).

\section{Histopathology}

No significant lesions were observed by histopathology in the pre-challenge (Day 0) group in either stock in any tissue (Fig. 1). Lesions in challenged fish were primarily observed in the kidney (interstitial tissue and glomeruli), liver (capsule and inner connective tissue stroma), spleen (capsule and parenchyma), and pancreatic interstitial tissue (Fig. 1). Hyaline thickening of the kidney glomerular basement membranes (membranous glomerulopathy), without marked proliferation of mesangial cells or infiltration of inflammatory cells, was observed as early as 14 dpi in the Green River stock but not until 42 dpi in the WI fish (Fig. 1A). When results from all time points (14 to $84 \mathrm{dpi}$ ) were combined, a greater number of Green River fish had observable glomerulopathy $(50 \%)$ relative to the WI fish $(30 \%)$. Granulomatous lesions were observed in the anterior and posterior kidney as early as 14 dpi in both stocks. The severity of kidney lesions at the 28 and 42 dpi time points was higher in the Green River stock, while the more severe lesions were not observed in the WI stock until 56 dpi (Fig. 1B,C). The severity and prevalence of lesions in the liver were similar between stocks although variation among time points was observed in the liver serosa (Fig. 1D,E). Lesions in the pancreatic interstitium were similar between stocks but slightly higher in the WI stock at later time points (Fig. 1F). Lesions were also observed in the spleen parenchyma/interstitium at low prevalence with a trend towards earlier onset of lesions in the Green River stock (Fig. 1G). Observations of lesions in the spleen capsule were more variable with no strong trend differentiating the stocks (Fig. 1H).

\section{Bacterial load}

Expression of the major soluble antigen (msa) gene and the $a b c$ transporter permease gene $(a b c)$ in the
cDNA samples was used as a proxy of bacterial load. No positive Renibacterium salmoninarum gene expression was detected in the mock control samples with either assay (data not shown). In the R. salmoninarum challenged group, msa gene expression increased over time (day: $F_{(4,77)}=3.7, \mathrm{p}=0.008$ ), but there was no significant difference between the stocks (Fig. 2A). Similar results were obtained with the $a b c$ assay (Fig. 2B), but too few individuals had detectable expression to draw statistical conclusions. There was a consistent but non-significant difference in bacterial load between the stocks at $28 \mathrm{dpi}$, suggesting the WI fish had a transient delay in bacterial replication.

\section{Immune gene expression}

Expression of the type II IFN gene, IFN- $\gamma$, was increased in both stocks treated with Renibacterium salmoninarum starting at $7 \mathrm{dpi}$. After $14 \mathrm{dpi}$, expression declined but remained elevated relative to mock controls until the final sampling point at $71 \mathrm{dpi}$ (Fig. 3A; treatment: $F_{(1,308)}=223.7, \mathrm{p}<0.001$; day: $F_{(4,308)}=7.6$, $\mathrm{p}<0.001$ ). iNOS gene expression increased in both stocks treated with $R$. salmoninarum relative to the mock groups (treatment; $F_{(1,308)}=9.5, \mathrm{p}=0.002$ ), and expression increased as time went on (day: $F_{(4,308)}=5.3$, $\mathrm{p}<0.001$ ) (Fig. 3B). At later time points, there was a suggestive trend of higher iNOS expression in the $R$. salmoninarum-treated Green River fish relative to the $R$. salmoninarum-treated WI fish, but there was no overall significant difference in iNOS expression between stocks (treated WI versus treated Green River $\mathrm{p}=0.054)$.

The type I IFN inducible gene $\mathrm{Mx}-1$ was moderately but consistently up-regulated by Renibacterium salmoninarum treatment (ranging from 1.5- to 4.2-fold) (Fig. 3C) at all time points relative to mock controls (treatment: $F_{(1,309)}=61.8, \mathrm{p}<0.001$ ), with varying overall levels depending on the day (day: $F_{(1,309)}=5.9$, p < 0.001). There was also a small but significant difference in $\mathrm{Mx}-1$ expression between fish stocks (stock: $\left.F_{(1,309)}=4.3, \mathrm{p}=0.04\right)$ with generally higher levels in the Green River.

The iron-binding transferrin gene was up-regulated in the Renibacterium salmoninarum-infected group relative to mock controls, with the level of expression differing between days (peak at $44 \mathrm{dpi}$; Fig. 3D) (treatment: $F_{(1,300)}=60.8, \mathrm{p}<0.001$; day: $F_{(4,300)}=6.4, \mathrm{p}<$ $0.001)$. Overall transferrin expression significantly differed between the 2 stocks (stock: $F_{(1,300)}=5.6, \mathrm{p}=$ $0.02)$, with transferrin expression generally higher in the $R$. salmoninarum-treated WI stock.

The overall expression of the gene encoding the Tcell receptor beta chain (TCR- $\beta$ ) was not consistent, 
A) Membranous glomerulopathy

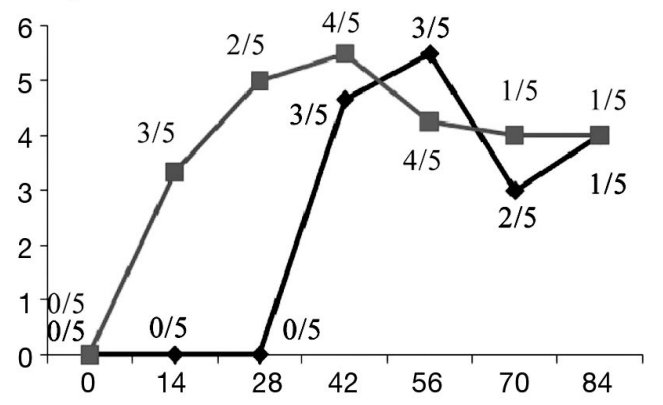

C) Posterior kidney

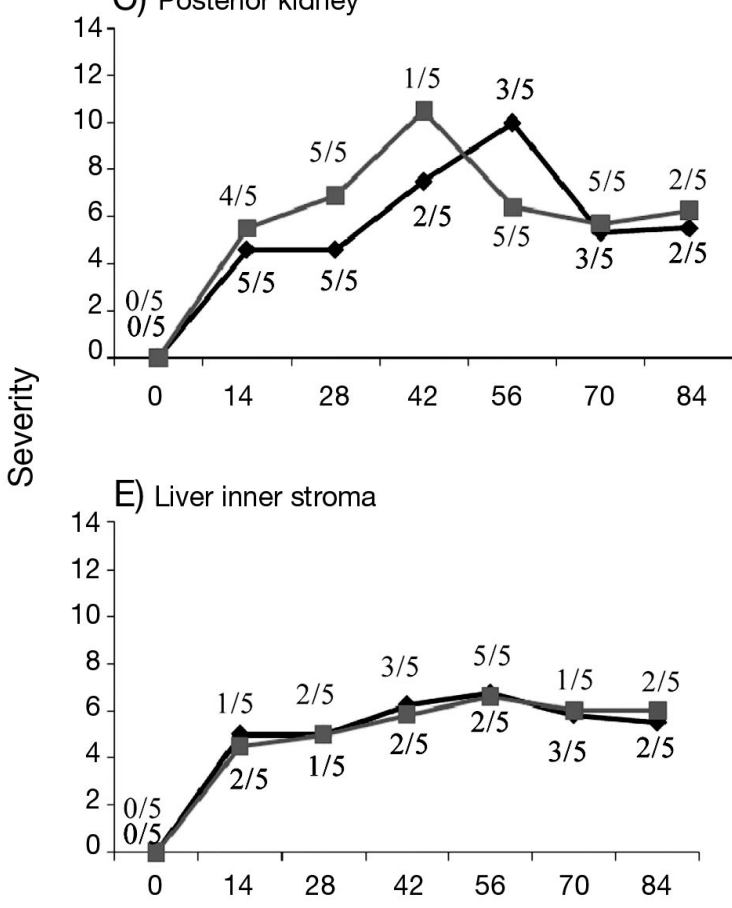

G) Spleen parenchyma

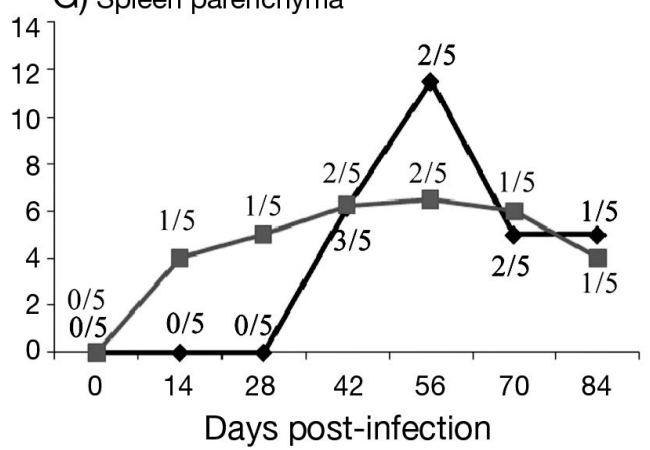

B) Anterior kidney

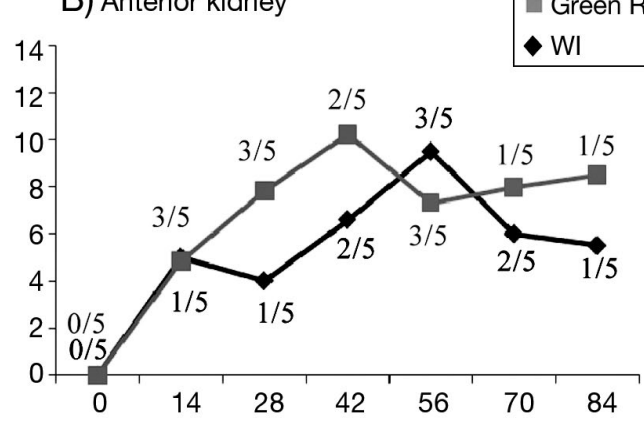

D) Liver capsule

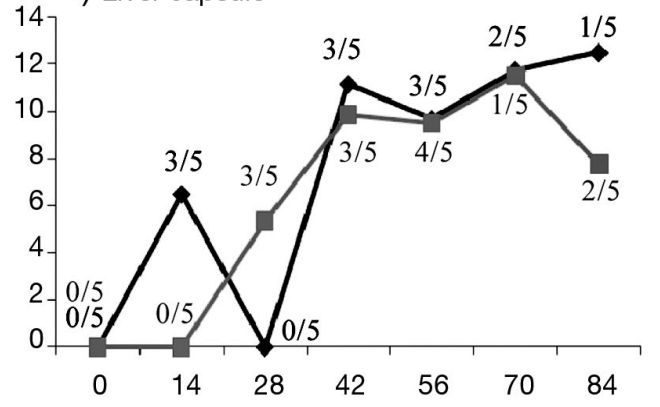

F) Pancreatic interstitium

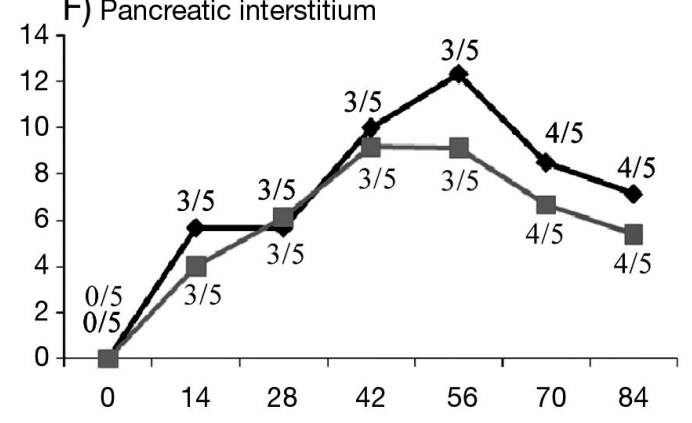

H) Spleen capsule

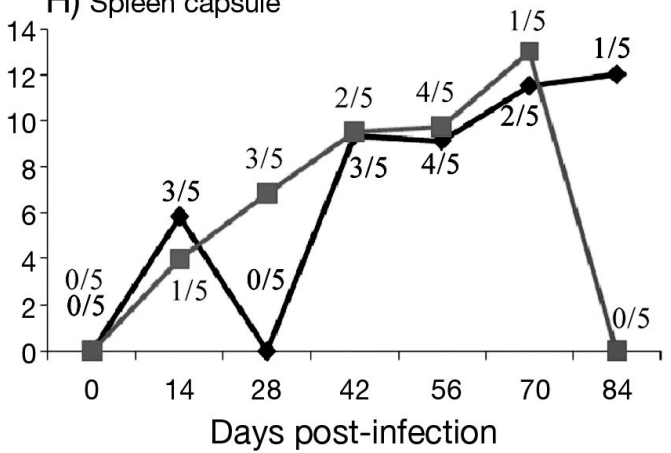

Fig. 1. Oncorhynchus tshawytscha. Histopathology results, from the 2003 cohort year, of Chinook salmon injected with Renibacterium salmoninarum. The tissue sections were stained with hematoxylin and eosin (H\&E). (A) Membranous glomerulopathy in the kidney glomeruli was scored using a scale that included distribution and severity. (B to H) Histopathological changes were scored using an additive scale that included size and distribution of lesions, and severity of inflammation and necrosis. The mean of the positive tissues for each group is shown on the $y$-axis, and lesion prevalence at each time point is shown above each data point (the number of positive fish divided by the number of fish examined) 

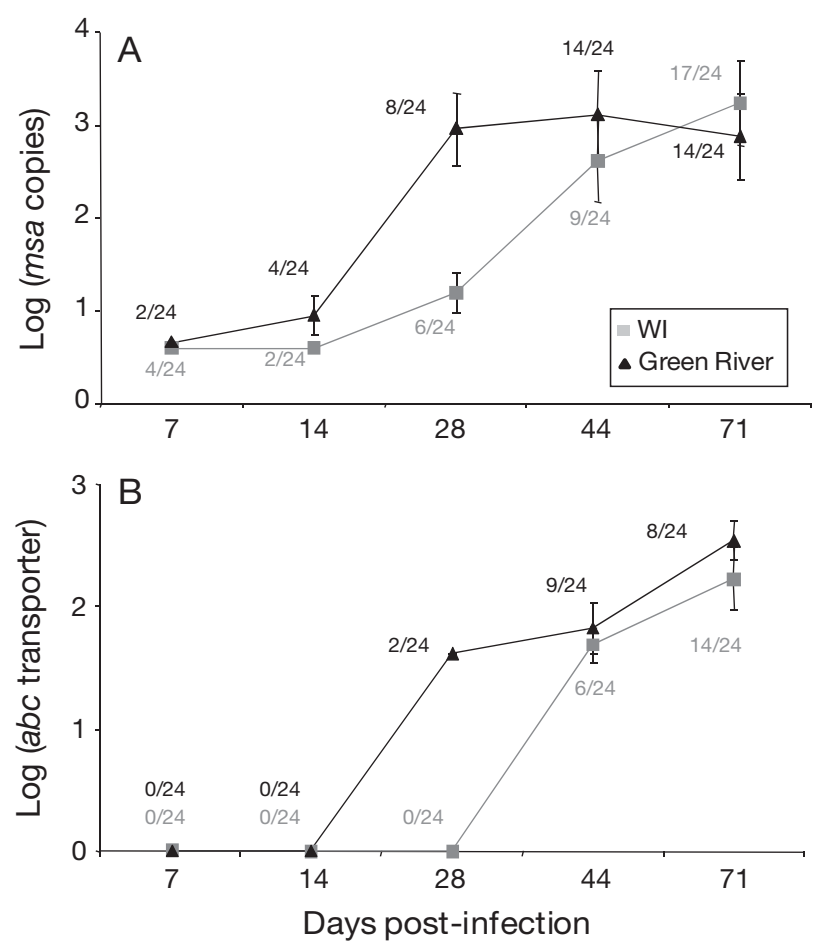

Fig. 2. Oncorhynchus tshawytscha. Mean log bacterial load $( \pm$ SE) in the Chinook salmon, in the 2005 cohort year, injected with Renibacterium salmoninarum. Bacterial load was estimated by the expression of the (A) major soluble antigen (msa) gene or (B) abc transporter permease gene by reversetranscriptase quantitative polymerase chain reaction (RTqPCR). Bacterial copy number was determined using a standard curve created using DNA extracted from quantified $R$. salmoninarum culture. Mean values for each time point were calculated using only the positive fish, and the number of positive fish divided by the number of fish examined is shown above each data point. WI: from Lake Michigan,

Wisconsin; Green River: from Green River, Washington

and regulation of the gene was dependent on a 3way interaction between stock, time, and treatment (stock ${ }^{*}$ time* treatment interaction: $F_{(4,297)}=4.3, \mathrm{p}=$ 0.002) (Fig. 3E) with high levels of expression in mock controls. Thus, no clear pattern could be discerned. Expression of the gene encoding the secreted form of IgM was also differentially regulated depending on the time and treatment (treatment: $F_{(1,285)}=27.8, \mathrm{p}<$ 0.001; day: $F_{(4,285)}=6.0, \mathrm{p}<0.001$ ) (Fig. 3F). At later time points $(\geq 14 \mathrm{dpi})$, there was a suggested trend towards higher expression in the treated groups, but there were no significant differences between the WI and Green River stocks (Fig. 3F).

\section{Immune gene expression correlated with bacterial load}

We examined the correlation between gene expression and bacterial load in individuals with de- tectable bacterial load. This analysis was restricted to the 28, 44, and 71 dpi time points, because most fish did not have detectable bacterial load at earlier time points. A significant correlation of bacterial load ( $m s a$ expression) with immune gene expression was observed for iNOS, IFN- $\gamma$, transferrin, and Mx-1 ( $\mathrm{p}<$ 0.001 all comparisons) but not TCR- $\beta$ or IgM. The iNOS gene was of particular interest because it had a consistent pattern of higher expression in the Green River stock at the later time points (Fig. 3B). However, this higher expression was not completely driven by higher bacterial load because the WI and Green River stocks had similar levels of bacterial load at 44 and 71 dpi (Fig. 2A,B). Correlation analysis of log bacterial load (msa expression) with iNOS expression indicated that both stocks had a proportional response to the bacterial load (evidenced by the similar slope of the lines in Fig. 4). However, for a given bacterial load level, the Green River stock had higher iNOS expression relative to the WI stock (evidenced by a greater $y$-intercept in the Green River stock; Fig. 4).

\section{DISCUSSION}

Granulomas are a typical host response to intracellular bacteria that function to contain the pathogen. However, recent studies indicate a role for granulomas in the early dissemination of the intracellular bacterium Mycobacterium marinum in zebrafish (Davis \& Ramakrishnan 2009). In the present study, the trend towards earlier appearance of more severe granulomatous lesions in the kidney in the more susceptible Green River stock was consistent with timing of mortality. Conversely, the trend towards lower prevalence and/or less severe lesions in each stock after peak mortality likely occurred because the remaining fish represented survivors. The lack of a strong difference in overall prevalence of kidney granulomas between stocks may have reflected the limited sample sizes ( 5 fish stock $^{-1}$ time point ${ }^{-1}$ ). The kidney is one of the main targets of Renibacterium salmoninarum, and loss of kidney function plays a role in BKD-induced mortality (Bruno 1986). The difference between the stocks was not consistent in other tissues, but the distribution and severity of lesions in visceral tissues may have been influenced by proximity to the intra-peritoneal injection site.

In humans, membranous glomerulopathy is associated with the accumulation of subepithelial immune complex deposits in kidney glomeruli and may occur in autoimmune disease, neoplasia, and infection (Markowitz 2001). Membranous glomerulopathy/ glomerulonephritis is also observed in Renibacterium salmoninarum-infected salmonids and is linked to 


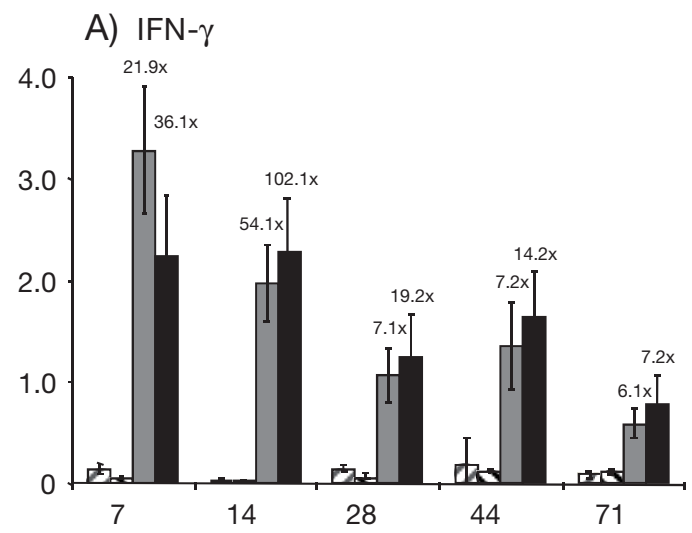

B) iNOS

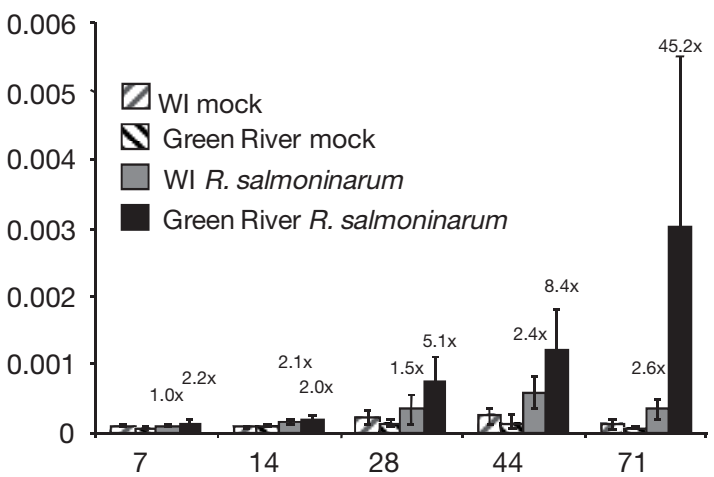

C) $\mathrm{Mx}-1$

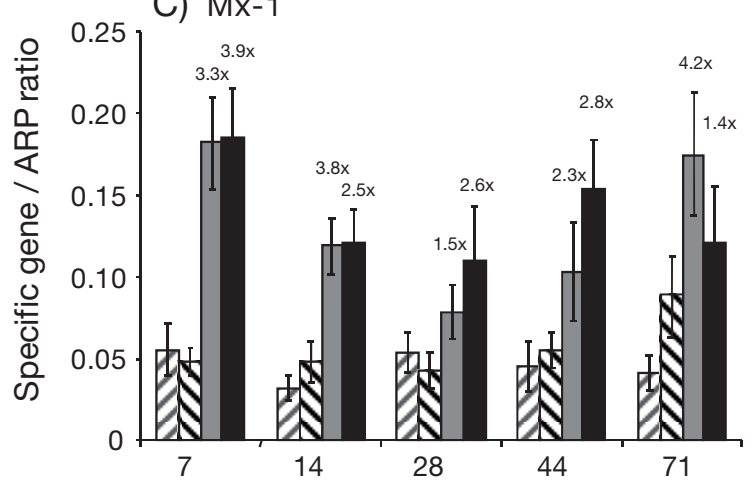

D) Transferrin
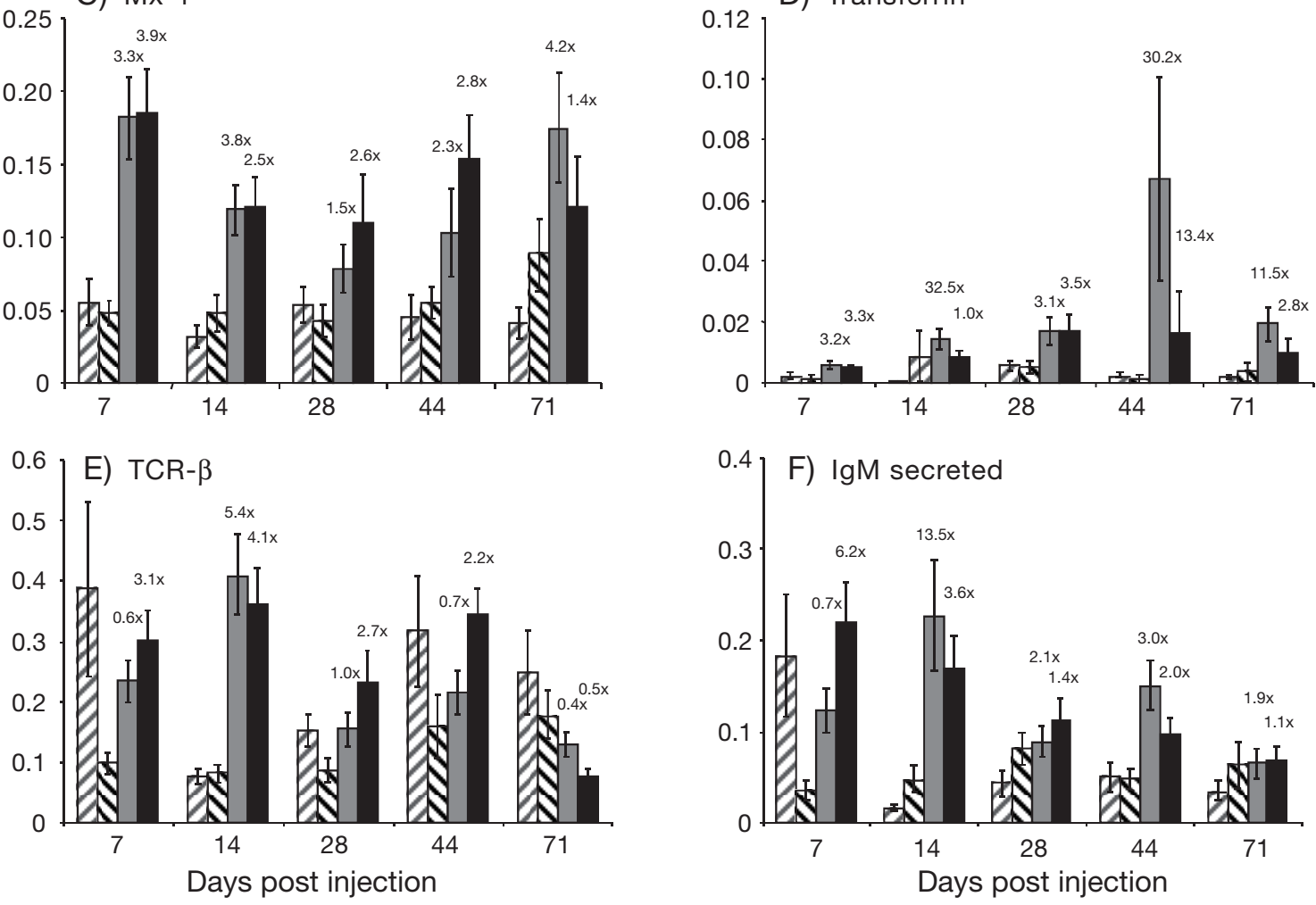

Fig. 3. Oncorhynchus tshawytscha. Normalized mRNA expression values in kidney tissue sampled from Chinook salmon injected with Renibacterium salmoninarum, as assayed by reverse-transcription quantitative polymerase chain reaction (RT-qPCR). (A) interferon gamma (IFN- $\gamma$ ), (B) inducible nitric oxide synthase (iNOS), (C) Mx-1, (D) transferrin, (E) T-cell receptor beta chain (TCR- $\beta$ ), and (F) immunoglobulin- $\mu$ (IgM) secreted form. Data are presented as mean \pm SE normalized ratios of the specific gene:normalizing gene (acidic ribosomal phosphoprotein P0; ARP) for each group and time point. Fold change values of

$R$. salmoninarum-challenged fish as compared to their respective mock controls are indicated above the histograms

antigen-antibody complex deposition in the glomeruli (Sami et al. 1992, Lumsden et al. 2008). This observation led to the hypothesis that an overzealous humoral response could exacerbate BKD-associated pathology (Wiens \& Kaattari 1999). The results of our study support the hypothesis that higher survival in the WI stock is associated with delayed onset and lower prevalence of immune-mediated glomerulopathy following $R$. salmoninarum infection.
The histopathology results led us to the hypothesis that the lower surviving Green River stock may produce a stronger antibody response against Renibacterium salmoninarum, leading to increased immune-mediated pathology. We sought to test this hypothesis by using the 2005 cohort year with an ELISA method that quantifies serum antibody titer to a recombinant p57 protein (Alcorn \& Pascho 2000) and by measuring gene expression of the secreted form of IgM. Serum samp- 


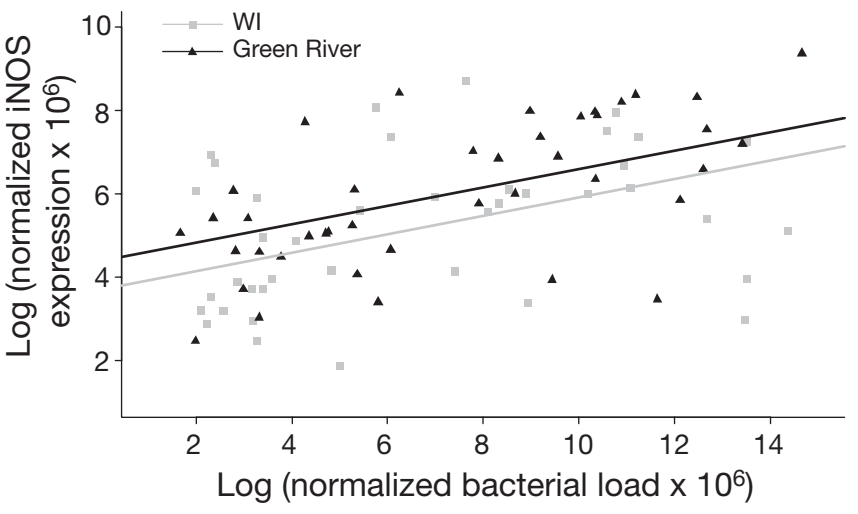

Fig. 4. Oncorhynchus tshawytscha. Correlation analysis of normalized msa gene expression (bacterial load) (Fig. 2A) with normalized inducible nitric oxide synthase (iNOS) expression (Fig. 3B) in the Wisconsin (WI) and Green River Chinook salmon stock sampled at 28,44 , and $71 \mathrm{~d}$ post-infection. Normalization was accomplished by dividing either the msa or iNOS expression by the normalizing gene ARP. Lines representing the best fit for each stock are shown $\left(\mathrm{r}^{2}=0.44\right.$; stock: $F_{(1,74)}=4.4, \mathrm{p}=0.04$; bacterial load $F_{(1,74)}=21.2, \mathrm{p}<0.001$; day $\left.F_{(4,74)}=8.0, \mathrm{p}<0.001\right)$

les from all time points ( 7 to $71 \mathrm{dpi}$ ) were tested by ELISA, but only 15 of 233 samples examined had detectable antibody levels, and there was no difference in prevalence between the stocks (data not presented). However, the sensitivity of the ELISA method was not fully validated for use in Chinook salmon. Expression of IgM did not significantly differ between stocks and, thus, more study is needed to fully characterize the humoral response to $R$. salmoninarum in these 2 stocks.

$\mathrm{T}$ cells are the primary mediators of protective immunity against intracellular pathogens (Kaufman 1999), but we lack many of the reagents necessary to directly measure T-cell activity in Chinook salmon. Instead, the present study relied on expression of the TCR- $\beta$ and IFN- $\gamma$ genes as proxy markers. In mammals, IFN- $\gamma$ is produced by natural killer and cytotoxic T cells (CTLs) and has a proven role in both early and late immune responses to intracellular bacteria (Kaufman 1999). TCR- $\beta$ and IFN- $\gamma$ gene expression did not differ between the stocks in the present study. However, we observed a significant rapid and sustained up-regulation of IFN- $\gamma$ expression following Renibacterium salmoninarum infection but no support for the hypothesis that the WI stock has higher T-cell response, as measured by IFN- $\gamma$ gene expression.

The regulation of $\mathrm{Mx}-1$ between the Green River and WI stocks following Renibacterium salmoninarum challenge was small in magnitude, and the biological significance of this result is uncertain. However, infection of mice with the intracellular bacterium Mycobacterium tuberculosis up-regulates the type I IFN system via conserved pattern recognition receptors (e.g. Toll- like and NOD-like receptors) and may play a role in priming or regulating the adaptive immune response (Pandey et al. 2009).

Competition for iron is important for survival of intracellular bacteria (Kaufman 1999). Transferrin is an iron-binding protein that sequesters iron from bacterial pathogens, acts as an acute phase protein, and has a number of functional roles in the innate immune response (Jurecka et al. 2009). Transferrin alleles have been genetically associated with survival following BKD challenge (Suzumoto et al. 1977, Winter et al. 1980), but there have been no functional studies confirming these results. In the present study, expression of transferrin significantly differed between the stocks after infection and was higher in the WI stock at later time points. Characterization of transferrin allelic variation in the 2 stocks would be of future interest.

The iNOS gene controls production of nitrogen radicals that serve as potent anti-bacterial molecules. Expression of the rainbow trout iNOS gene is rapidly up-regulated in the gills and posterior kidney after Renibacterium salmoninarum infection (CamposPerez et al. 2000). Avirulent and virulent strains of $R$. salmoninarum increased serum nitrate (functional measure of iNOS) in trout, with the highest nitrate response observed in fish that received the virulent strain (MT1729) and suffered the highest mortality (Campos-Perez et al. 2000). The $R$. salmoninarum genome possesses at least 2 candidate genes that may be involved in sensing and resisting nitrogen radicals (Wiens et al. 2008). The finding that the Green River stock had higher iNOS expression, even after accounting for the effect of bacterial load, suggests the possibility that higher nitric oxide production may have contributed to greater host cell collateral damage, leading to greater pathology.

The phenotypic difference in survival between the WI and Green River stocks is not absolute; rather, a different proportion of fish within each stock survives or succumbs following challenge. Furthermore, Renibacterium salmoninarum infections tend to be asynchronous among individual fish because of the slow replication rate of the bacterium. These factors combined likely contributed to the variation in responses we observed between stocks and among time points, despite using robust sample sizes (24 fish group ${ }^{-1}$ ). Future studies that examine both inter- and intra-stock responses may represent a more powerful approach.

One potential mechanism for higher survival in the WI stock may be enhanced ability to resist Renibacterium salmoninarum, with 'resistance' defined as the ability to limit the pathogen (e.g. by limiting bacterial replication or spread). Alternatively, higher survival may be due to the ability of the WI fish to tolerate the infection, perhaps due to a dampened immune re- 
sponse or by mechanisms that can compensate for pathology. Under a 'tolerance' scenario, high and low tolerant populations would have equivalent pathogen burden, but the more tolerant stock would have less pathology (Raberg et al. 2007). Here, we demonstrate that bacterial load was transiently higher in the Green River stock at the 28 dpi time point, supporting the 'resistance' hypothesis. However, by 44 dpi the 2 stocks had similar bacterial load levels, but the Green River stock was experiencing higher levels of mortality at that time point, providing support for the 'tolerance' hypothesis.

\section{CONCLUSIONS}

Higher survival of the WI stock was associated with lower prevalence of immune-mediated pathology. We did not observe a consistent enhancement or dampening of immune gene expression in the WI fish across all genes, but rather the differences between the stocks varied depending on the gene. One of the striking findings of this study was the sustained upregulation of most immune genes after infection out to $71 \mathrm{dpi}$. To our knowledge, this is the first study to examine immune gene responses to Renibacterium salmoninarum over a long time course. We observed consistently higher iNOS gene expression in the low survival WA stock at later time points, which could contribute to greater immune-mediated pathology in that stock. Except for a transient difference at $28 \mathrm{dpi}$, bacterial load was similar in both stocks despite higher mortality in the WA stock. The results of this study suggested a role for both the 'resistance' and 'tolerance' hypothesis in explaining higher survival of the WI fish. Ongoing studies in our laboratory are designed to explicitly test this hypothesis. Distinguishing between these 2 hypotheses would have implications for understanding the evolution of this host-pathogen relationship. Greater tolerance of $R$. salmoninarum infection by the Chinook salmon host may facilitate vertical transmission of the bacterium if infected fish survive to spawning. Thus, enhanced tolerance can benefit the fitness of both the host and pathogen.

Acknowledgements. The authors are grateful for the support provided by S. Marcquenski (Wisconsin Department of Natural Resources) and M. Wilson (Washington Department of Fish and Wildlife). The authors acknowledge the technical assistance of S. Alcorn, A. L. Murray, L. M. Applegate, C. McKibben, and C. Conway at the Western Fisheries Research Center. Funding for this project was provided by the US Geological Survey, National Marine Fisheries Service (NOAA), and the Great Lake Fisheries Trust (Project No. 2008.966). The use of trade, firm, or corporation names in this publica- tion is for the information and convenience of the reader. Such use does not constitute an official endorsement or approval by the US Department of Interior or the US Geological Survey of any product or service to the exclusion of others that may be suitable.

\section{LITERATURE CITED}

Alcorn SW, Pascho RJ (2000) Single-dilution enzyme-linked immunosorbent assay for quantification of antigenspecific salmonid antibody. J Vet Diagn Invest 12:245-252

Bartholomew JL, Arkoosh MR, Rohovec JS (1991) Demonstration of the specificity of the salmonid humoral responses to Renibacterium salmoninarum with a monoclonal antibody against salmonid immunoglobulin. J Aquat Anim Health 3:254-259

> Bruno DW (1986) Histopathology of bacterial kidney disease in laboratory infected rainbow trout, Salmo gairdneri Richardson, and Atlantic salmon, Salmo salar L. with reference to naturally infected fish. J Fish Dis 9:523-537

Campos-Perez JJ, Ward M, Grabowski PS, Ellis AE, Secombes CJ (2000) The gills are an important site of iNOS expression in rainbow trout Oncorhynchus mykiss after challenge with the Gram-positive pathogen Renibacterium salmoninarum. Immunology 99:153-161

> Chase DM, Elliott DG, Pascho RJ (2006) Detection and quantification of Renibacterium salmoninarum DNA in salmonid tissues by real-time quantitative polymerase chain reaction analysis. J Vet Diagn Invest 18:375-380

Chien MS, Gilbert TL, Huang C, Landolt ML, O'Hara PJ, Winton JR (1992) Molecular cloning and sequence analysis of the gene coding for the $57-\mathrm{kDa}$ major soluble antigen of the salmonid fish pathogen Renibacterium salmoninarum. FEMS Microbiol Lett 96:259-266

Davis JM, Ramakrishnan L (2009) The role of the granuloma in expansion and dissemination of early tuberculous infection. Cell 136:37-49

> Elliott DG, Barila TY (1987) Membrane filtration-fluorescent antibody staining procedure for detecting and quantifying Renibacterium salmoninarum in coelomic fluid of Chinook salmon (Oncorhynchus tshawytscha). Can J Fish Aquat Sci 44:206-210

Elliott DG, Pascho RJ, Jackson LM, Matthews GM, Harmon JR (1997) Renibacterium salmoninarum in spring-summer Chinook salmon smolts at dams on the Columbia and Snake Rivers. J Aquat Anim Health 9:114-126

Evelyn TPT (1977) An improved growth medium for the kidney disease bacterium and some notes on using the medium. Bull Off Int Epizoot 87:511-513

Evelyn TPT, Prosperi-Porta L, Ketcheson JE (1990) Two new techniques for obtaining consistent results when growing Renibacterium salmoninarum on KDM2 culture medium. Dis Aquat Org 9:209-212

> Ford MJ (2001) Molecular evolution of transferrin: evidence for positive selection in salmonids. Mol Biol Evol 18: 639-647

Fryer JL, Lannan CN (1993) The history and current status of Renibacterium salmoninarum, the causative agent of bacterial kidney disease in Pacific salmon. Fish Res 17:15-33

> Grayson TH, Cooper LF, Wrathmell AB, Roper J, Evenden AJ, Gilpin ML (2002) Host responses to Renibacterium salmoninarum and specific components of the pathogen reveal the mechanisms of immune suppression and activation. Immunology 106:273-283

Gutenberger SK, Duimstra JR, Rohovec JS, Fryer JL (1997) Intracellular survival of Renibacterium salmoninarum in 
trout mononuclear phagocytes. Dis Aquat Org 28:93-106 Holey ME, Elliott RF, Marcquenski SV, Hnath JG, Smith KD (1998) Chinook salmon epizootics in Lake Michigan: possible contributing factors and management implications. J Aquat Anim Health 10:202-210

Jansson E, Ljungberg O (1998) Detection of humoral antibodies to Renibacterium salmoninarum in rainbow trout Oncorhynchus mykiss and Atlantic salmon Salmo salar challenged by immersion and in naturally infected populations. Dis Aquat Org 33:93-99

Jurecka P, Irnazarow I, Stafford JL, Ruszczyk A and others (2009) The induction of nitric oxide response of carp macrophages by transferrin is influenced by the allelic diversity of the molecule. Fish Shellfish Immunol 26: 632-638

Kaufman SHE (1999) Immunity to intracellular bacteria. In: Paul WE (ed) Fundamental immunology, Vol 4. LippincottRaven Publishers, Philadelphia, PA, p 1335-1371

Kurath G, Garver KA, Corbeil S, Elliott DG, Anderson ED, La Patra SE (2006) Protective immunity and lack of histopathological damage two years after DNA vaccination against infectious hematopoietic necrosis virus in trout. Vaccine 24:345-354

Lumsden JS, Russell S, Huber P, Wybourne BA, Ostland VE, Minamikawa M, Ferguson HW (2008) An immune-complex glomerulonephritis of Chinook salmon, Oncorhynchus tshawytscha (Walbaum). J Fish Dis 31:889-898

Markowitz GS (2001) Membranous glomerulopathy: emphasis on secondary forms and disease variants. Adv Anat Pathol 8:119-125

Pandey AK, Yang Y, Jiang Z, Fortune SM and others (2009) NOD2, RIP2 and IRF5 play a critical role in the type I interferon response to Mycobacterium tuberculosis. PLoS Pathog 5:e1000500, doi:10.1371/journal.ppat.1000500

Pascho RJ, Elliott DG, Streufert JM (1991) Broodstock segregation of spring chinook salmon Oncorhynchus tshawytscha by use of the enzyme-linked immunosorbent assay (ELISA) and the fluorescent antibody technique (FAT) affects the prevalence and levels of Renibacterium salmoninarum infection in progeny. Dis Aquat Org 12:25-40

Pierce AL, Dickey JT, Larsen DL, Fukada H, Swanson P, Dickhoff WW (2004) A quantitative real-time RT-PCR assay for salmon IGF-I mRNA and its application in the study of GH regulation of IGF-I gene expression in primary culture of salmon hepatocytes. Gen Comp Endocrinol 135:401-411

Purcell MK, Kurath G, Garver KA, Herwig RP, Winton JR (2004) Quantitative expression profiling of immune response genes in rainbow trout following infectious

Editorial responsibility: David Bruno, Aberdeen, UK haematopoietic necrosis virus (IHNV) infection or DNA vaccination. Fish Shellfish Immunol 17:447-462

Purcell MK, Murray AL, Elz A, Marcquenski SV and others (2008) Decreased mortality of Lake Michigan Chinook salmon (Oncorhynchus tshawytscha) following bacterial kidney disease challenge: evidence for pathogen-driven selection? J Aquat Anim Health 20:225-235

Raberg L, Sim D, Read AF (2007) Disentangling genetic variation for resistance and tolerance to infectious diseases in animals. Science 318:812-814

Rhodes LD, Durkin C, Nance SL, Rice CA (2006) Prevalence and analysis of Renibacterium salmoninarum infection among juvenile Chinook salmon Oncorhynchus tshawytscha in North Puget Sound. Dis Aquat Org 71:179-190

Rhodes LD, Wallis S, Demlow SE (2009) Genes associated with an effective host response by Chinook salmon to Renibacterium salmoninarum. Dev Comp Immunol 33: 176-186

Sami S, Fischer-Scherl T, Hoffmann RW, Pfeil-Putzien C (1992) Immune complex-mediated glomerulonephritis associated with bacterial kidney disease in rainbow trout (Oncorhynchus mykiss). Vet Pathol 29:169-174

Suzuki K, Sakai DK (2007) Real-time PCR for quantification of viable Renibacterium salmoninarum in chum salmon Oncorhynchus keta. Dis Aquat Org 74:209-223

Suzumoto BK, Schreck CB, McIntyre JD (1977) Relative resistance of three transferrin genotypes of coho salmon (Oncorhynchus kisutch) and their hematological responses to bacterial kidney disease. J Fish Res Board Can 34: $1-8$

Weeder JA, Marshall AR, Epifanio JM (2005) An assessment of population genetic variation in Chinook salmon from seven Michigan rivers 30 years after introduction. N Am J Fish Manag 25:861-875

Wiens GD, Kaattari SL (1999) Bacterial kidney diseases (Renibacterium salmoninarum). In: Woo PTK, Bruno DW (eds) Fish diseases and disorders, Vol 3. CAB International, Wallingford, p 269-302

> Wiens GD, Rockey DD, Wu Z, Chang J and others (2008) Genome sequence of the fish pathogen Renibacterium salmoninarum suggests reductive evolution away from an environmental Arthrobacter ancestor. J Bacteriol 190: 6970-6982

Winter GW, Schreck CB, McIntyre JD (1980) Resistance of different stocks and transferrin genotypes of coho salmon, Oncorhynchus kisutch, and steelhead trout, Salmo gairdneri, to bacterial kidney disease and vibriosis. Fish Bull 77:795-802

Submitted: September 18, 2009; Accepted: February 15, 2010 Proofs received from author(s): May 6, 2010 